\title{
海外情報
}

\section{環境先進国ドイツにみるリサイクル戦略 事例研究}

\section{1. 戦略的リサイクル推進の背景}

\section{1 ドイツの環境政策は新しい産業政策}

世界でもっとも環境対策の進んでいる国ドイッで も，かって急激な成長による北海の污染，酸性雨に よる森林破壊,身近なところではあふれるごみ処理, 焼却によるダイオキシンといつた環境破壊を経験し た．その反省から「エコロジー的に非合理なものは 経済的にも非合理である.エコロジーは経済の付属 物ではない」(ドイツ統一の中核となった西ドイツ社 会民主党の新綱領）という基本理念のもとに，産業 や社会の仕組みを強引ともいえるほど急速な勢いで 「循環型社会」へ転換してきた。ドイツ政府のやり 方は，環境政策というよりも次の時代の国家競争力 を高めるための産業政策であるといっても過言では ない.

その背景に「目先の利益や経済成長を優先する雾 囲気が強く，とにかく遅れた経済に追いつき，余裕 ができてから環境問題に対処していけばよい」とい う姿勢への厳しい反省がある。このことは，企業経 営においても同じことがいえる．環境問題への取組 みが遅れれば遅れるほど負担が大きくなり，結果的 に競争に大きく敗北することになるのである.

\section{2 エコロジー重視の「循環経済法」}

ドイツのごみとリサイクルに関する法律の基本 は，廃棄物を発生させないことにある。それが，「包 装廃棄物回避に関する政令」の制定であるし，自動 車メーカーに対しての廃車の無料引取りを義務づけ る法制化の準備である。

そして，1994年には「循環経済の促進及び環境と 調和する廃棄物処分の確保に関する法律」(循環経 済・廃棄物法）が制定された。この法律の特徴は,

*金蘭短期大学, リサイクル経済研究所

Tetsuhiko YOSHIMURA
吉 村 哲 彦*

従来市民へのごみ減量や分別排出の義務づけが厳し かったのに対し，販売・流通とかもっと川上のメカーへの義務づけが弱かったことへの反省を踏まえ たものである点だ．わかりやすくいえば，川上で污 れた水，川上や川中で污れの原因をつくっている場 合，川下でいくら努力しても限界があるということ である。そこで，川上や川中のメーカーや流通業者 に，ごみになるものを作らせないようにする，そし て回収やリサイクルの義務づけを法的に規制しょう とする画期的なものである.

同時に，ドイツにおけるリサイクルの推進，環境 保全はドイツ人気質に負うところが大きい。ドイツ には「生活の半分は法的な秩序 (Ordunung)である。 秩序がしっかりしていれば生活は大丈夫だ」という 主旨の諺があるが，リサイクルについても，企業や 市民が法律や秩序を遵守しようとするところにドイ ツたる所以がある。

そして,ドイツの常識として, 連邦政府, 州, 市 は，市民に対しごみの発生回避，徹底的な分別排出 をマスコミ，学校，スポーツクラブなどあらゆるメ ディアを使って周知徹底させている．金銭的動機づ けとしても，各家庭からでるごみは量に応じて料金 が徵収されている．だから分別排出すればごみ処理 費が減るのである．都市によって若干異なるが，フ ランクフルト市の平均的世帯で，年間 2 万円ほどで ある，参考までに，東京都では， 1 人分のごみ処理 費が年間 3 万円ほどかかっている．ドイツとの根本 的な違いは「ごみをいくら出してもただ」という日 本の考え方である.ドイツをはじめ欧州のほとんど の国は家庭から排出されるごみは有料である.また， 日本，ドイツ，アメリカの 3 国のごみ処理の実態は, 焼却施設をみてもわかるように，日本が1854ヶ所， ドイツ53, 米国148と桁違いである (表 1 参照).

「百聞は一見にしかず」で，環境先進国ドイツの 


\section{表 1 ドイツ, 日本, 米国のごみ処理の比較}

\begin{tabular}{c|r|r|r}
\hline & $\begin{array}{r}\text { ドイツ } \\
(1993)\end{array}$ & $\begin{array}{r}\text { 日 本 } \\
(1993)\end{array}$ & $\begin{array}{l}\text { 米 国 } \\
(1993)\end{array}$ \\
\hline $\begin{array}{c}\text { ゴミ発生量 } \\
\text { (千トン/年) }\end{array}$ & 43,500 & 50,300 & 207,000 \\
\hline $\begin{array}{c}\text { ゴミ焼却量 } \\
\text { (千トン/年) }\end{array}$ & 11,000 & 38,000 & 32,900 \\
\hline $\begin{array}{c}\text { ゴミ焼却(\%) } \\
\text { 直接埋立(\%) }\end{array}$ & 25 & 74 & 16 \\
\hline $\begin{array}{c}\text { ゴミ焼却施設数 } \\
\text { (カ所) }\end{array}$ & 53 & 15 & 62 \\
\hline \multicolumn{2}{|c|}{5} & 1,854 & 148 \\
\hline
\end{tabular}

ごみ問題やリサイクルの実態を, 自治体, スーパー, リサイクル事業に関して調査する機会に恵まれたの でその事例を紹介したい（1998年 6 月末から 7 月初 旬まで, 吹田商工会議所 50 周年記念事業として, 視 察・調査したものである).

\section{2.〔事例 1〕ハイデルベルク市のごみ処理 とリサイクル}

\section{1 ハイデルベルク市のごみ処理}

ハイデルベルク市の清掃局ごみ処理技術担当のハ ーフマン氏より当市のごみ処理の理念, 現在のシス テム，このシステムができるまでの経緯などの説明 を受け，その後の質疑応答に移った。それをまとめ たものである.

当市はドイツ最古の大学と中世の城が織りなす古 都である.人口はドイツ人 13 万人と米軍 2 万人合計 15万人である。

ごみ処理に関する基本理念として次の 4 つを掲げ ている。

(1)ごみ総量の減少

(2)各家庭でのコンポストの推進

(3)再利用容器の割合を増やす（リターナブル容器）

(4)2000年までに現在（1997年度）のごみ焼却量年間 45,000トンを41,000トンに減らす（NATO，米軍 設備からのごみを含む)

\section{2 当市のごみ処理方法}

1984年の家庭から排出されたごみは，再生できな い焼却ごみが $93 \%$ を占めていた。ごみ焼却設備が古 くなり排煙処理の困難などから一時フランスへごみ を輸出し，処理してもらうなどして窮地を切り抜け てきた.

1986年よりごみの焼却を中止し，新しい設備をつ
くらず, 隣接のマンハイム市に焼却を委託している. このシステムを設計するにあったての基本理念はで きるだけごみを減らし，徹底したリサイクルの推進 にあった，その内訳はびん，缶などの包装材のリサ イクルが， $7 \%$ から， $20.2 \%$ に，そして 97 年には 42.8 \%にまで増加し，今後一層増やそうとしている．同 時に生ごみのコンポストの推進を進めている。ごみ 処理の内訳を 91 年，97年と比較すると，91年には焼

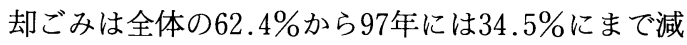
らすことができた.

\section{3 ごみ減量とリサイクル推進の実施方法}

ごみに対する当市の基本理念をその実施につい て，現在までの実績をあげてきた経過を次にみるこ とにする.「減らす方法」,「再利用の方法」,「焼却方 法」の 3 つをきめ細かく明示している.

(1)「減らす方法」

(1)金銭的動機づけとして,ごみ処理費を值上げし， 同時に，収集の間隔も 1 週間に 1 回から 2 週間 に 1 回に延ばし，ごみを出しにくくした。

(2)従量制を採用した。

(3)市民にごみ処理のことを周知徹底させるため に, 廃棄物に関するカレンダー, パンフレット, 広報, 展示会, 宣伝カーとあらゆる機会を利用 した。

(4)植栽ごみのコンポストを各家庭で推進させた.

(5)レストラン，軽食喫茶などでの再利用容器使用 の義務づけを協定した。

(2)「再利用の方法」

第 1 は, DSD（デュアル・システム・ドイチェラ ンド)社などとのリサイクルの推進である．500メー トル毎に設置したコンテナ容器にビンの色別に分け て入れる. 缶, PET 容器も分けていれる. 古紙など も指定されたコンテナに入れる，古紙の回収実績を 見ると，1984年の 1 トン弱から，1995年には 1 万 2 千トンにまで増えている（写真 1 ）。

第 2 は，各家庭でのコンポストと市主導のバイオ ごみの堆肥化である.野菜，コーヒーのフィルター， ティーバッグ, 園芸でのごみなどはバイオごみとし て，堆肥にする．そのために，魚や肉などの台所の ごみとは分けて出さねばならない. 1972年に, 台所 のごみなども入れた堆肥を作ったが，有毒のものが 含まれることがあり中止した。1985年から，ごみ焼 却を当市が止めたことから, 各家庭での生ごみのコ ンポストと市主導のバイオごみ（植栽のコンテナ収 


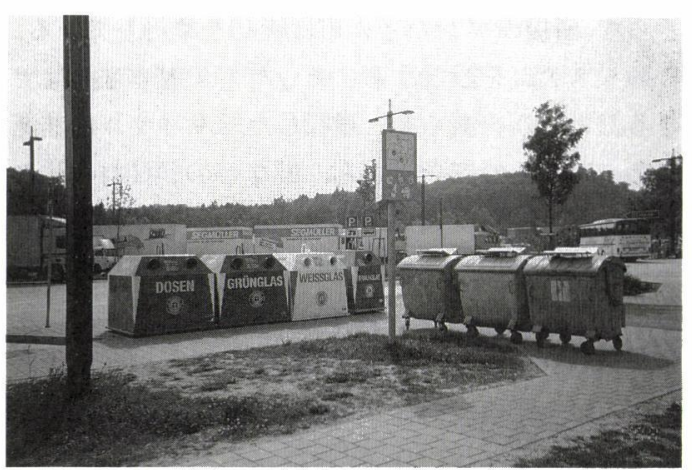

写真 1 サービスエリアでの DSD 社回収コンテナ

集）リサイクルを始めた。

バイオごみは，8cm以下のごみにして，60-70\% の水分を 10 週間以上寝かせることで，水分 $30 \%$ 以下 の肥料にする。

市は堆肥処理場として, 面積 $36 \mathrm{~m}$ 四方の農場のよ うな設備に 2,000 万マルク，悪臭除去に 5,000 万マル クの設備投資をした。従業員 20 人，処理能力 3 万 5 千トン, 1トンあたりの処理費350マルクという，本 格的なバイオごみの処分場である.

できた堆肥は 1 トンあたり35マルクでぶどう畑の 土壤改良材として販売している。昨年度で 1 万 2 千 トンが販売された。

現在は採算に合っていないが，ドイツ政府はごみ 処理の基本を堆肥化におき，ごみ減量化の残された 唯一の領域と捉らえている。 ドイツ全体のごみ量 3 千万トンの 3 分の 1 が堆肥可能という政策の基に推 進している．現在ではホテル，レストランなどの生 ごみは家畜飼糧とか各事業所でのコンポストで処理 することになっており，市の回収にはだせない。

第 3 は, ガレージセール，不用品の交換などの推 進も強力に進めた。

耐久消費財，衣服などは気楽に販売している。

(3)「焼却方法」

「焼却方法」では，現在は焼却は中止し，今後も 焼却炉は持たないことを決めている。1996年から隣 接のマンハイム市の焼却場に持ち込み処理してもら つている. 焼却ごみは 1 トン 500 マルクと高額であ り，できるだけ減らすように努力している．97年度 は 4 万 5 千トン（NATO，米軍のごみを含む）持ち 込んでいる。かつては，ごみをフランスに持ち込ん でいたが，バーゼル条約によって不可能になったこ とがごみ隇量とリサイクルの推進に拍車をかけたこ
とも事実である.2000年までに 4,000 トン減らすこと を当市のごみ問題の目標に入れている。八イデルべ ルク市をはじめドイツの各都市のごみ処理は基本的 にすべて有料である，各家庭ではごみを入れる容器 は, 市当局から借りている. 容器の大きさに応じて ごみ処理料が異なる．夫婦子供 2 人という標準世帯 で60リットルの容器になる。ごみ容器の種類は家庭 では 2 種類で, 緑のごみ箱と黒のごみ箱があり, 緑 の箱には, 菜園, 植栽, 野菜などの生ごみである. 黒の箱には分解しにくい骨や紙オムッ，生理用品な ぞその他のごみを入れる.ただし, 容器包装材とし て無料のグリーンマークの付いたものは黄色の DSD 社のふくろに入れる.ドイツの古都八イデルベ ルクも，環境，ごみ処理，リサイクルで視察すると あたらしい街としての古都が見えてくるのが興味深 かった。

\section{3.〔事例 2〕グローブス}

\section{1 グローブスの経営理念}

1986年に創立されたドイツの中堅スーパーであ る. 現在, 全国74店埔, 売上高52億マルク, 従業員 数 13,000 人，売り場面積700万平方メートルである. グループ全体の $85 \%$ がスーパー，八イパーであり， 15\%は建築資材，DIY などの販売である。ここ10年 間，順調な成長をはたしている。

取材した店舗はミュンヘンに近いゲジングン市の ハイパーマーケットである。ここで，グローブスの 環境担当の役員であるギラミー氏を中心にドイツの 容器包装のあり方，環境によい店舗とはどういうこ とかの説明を受けそれから質疑応答に移った。

「我々は地域社会と環境に対して，義務を負わさ れている」という社是を揭げて経営を営んでいる. だから，環境問題ばかりでなく，商品の品質として 賞味期限の厳守，もし守られてないときは 5 マルク の罰金を支払う。また，サービスの強化ということ からレジで10分以上待たせたときは 5 マルクの罰則 金を支払うなど具体的に対応している。

スーパーの経営の基本は, 法律と顧客に適応して いくことである．ドイツでは戦後のめざましい経済 成長ととも年々増加する廃棄物, 有害廃棄物に対し て, 100年前と変わら娌立て, 焼却中心の処理に限 界がみえた。そのため, 次の 3 点を目的に1972年「廃 棄物除去法」が制定された。

(1)生産から消費段階で廃棄物をどのように減量化 


\section{するか}

(2)リサイクルを一層推進すること

(3)有害廃棄物をどう適正に処理するにはどうする 少

ごみに対するドイツ人の考えは大きく変わった が, 無責任な行動, 不十分な知識により, 使い捨て 容器は増える一方であった。

1986年「廃棄物の回避及び管理法」が制定され， ごみの減量化，リサイクルを中心に置くことになっ た。同時に，ごみは資源であるという施策をとった。

この時期から，清涼飲料などの容器はデポジット 制度が採用され，スーパーなどに持って行くと預か り金を返してくれるシステムが普及した。プラスチ ック容器にもこの制度が採用された。たとえば，2 リットル容器は 2 マルク, 1.5リットルは 1 マルクで ある。そして，1991年には，「包装廃棄物回避のため の政令」という先進国の中でも最も厳しい法律が制 定された，製造，流通の業者に包装廃棄物の回収と 再資源化を義務づけたものである。

この具体的な動向として販売，消費，包装材の関 連企業が出資して DSD 社を設立した. 社名は, 二重 システムという意味で, 従来, ごみは自治体が回収, 処理していたが，それ以外に企業による包装材の回 収，処理，リサイクルを並行して実施することから 付けられた。財源は，各商品に付けられているグリ ューネ・プンクト（緑のリサイクルマーク）のライ センスを供与し，商品価格に上乗せすることで賄っ

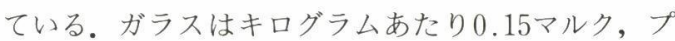
ラスチック類は2.95マルクというように素材によっ て格差をつけている。この政令と DSD 社によって， 自治体のごみ量は減少したし, 企業は過剰包装, リ サイクルを配慮した包装に転換していった。

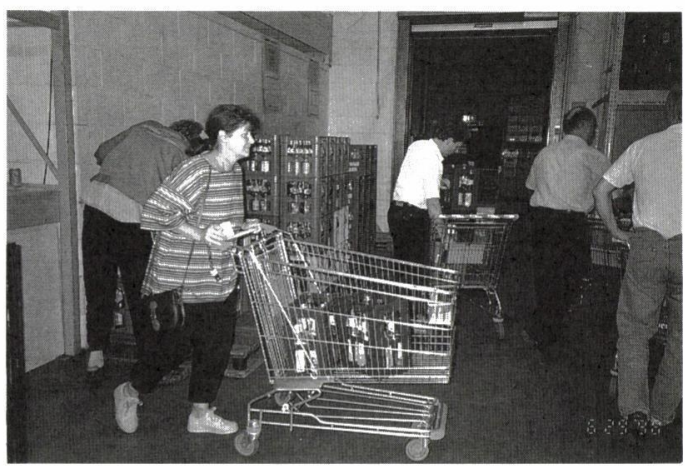

写真 2 使用済容器の返却

\section{2 ゲジンゲン店での見学}

このようなドイツの国家的な環境への取組みによ って個別企業もそれに対応していかねば消費者から も見放されかねない状況に追い込まれたのである。

当スーパーの順調な成長は環境対策に成功したこ とを裏付けるものである。

1985年以来，毎年，専門の調査会社 (GFK 社) に 依頼して顧客の当社に対する「環境調査」をしてい る。その一例がスーパーの環境対策に満足している かどうかについてであるが，85年には「満足」39\%， 現在の97年は「満足」が $60 \%$ に上昇している。調査 の内容㟄細で，古紙についての「再生品を購入す る」が43\%と高いが，旧東ドイツにある店舗ではい まだに $31 \%$ と低いなど地域による格差も調べてい る.ゲジンゲン店でのリサイクルの実態については, 日本のスーパーとかなりの相違がある。

スーパーに買物に来る客はまず店舗備え付きの台 車で, 使用済みの容器を預かり金戻しレジへ返し, 返却金伝票を受け取る。P箱にびん, PET ボトルを いれたものを戻すと, $\mathrm{P}$ 箱 3 マルク, 大びん 1 マル ク，小びん，PET ボトルなどは 5 ペニヒである.

平均一人あたり 35 マルクの返却金を伝票でもら い，商品を購入したときその伝票を使う。ワイン， 清涼飲料, ビール, 調味料など液体の容器は基本的 にデポジットの容器で販売していた. 缶, 使い捨て 容器の販促のメーカーの商品への誘惑もあるが 8 割 がデポジット容器で販売している (写真 2,3 ).

店内での生鮮 3 品についても, 野菜, 果物などは ノ一包装で販売しているし，また包装した物があっ ても価格で差をつけていた。肉，ソーセージなども いたって簡単な包装ですましているし，日本のよう に塩ビでの包装はしていない.

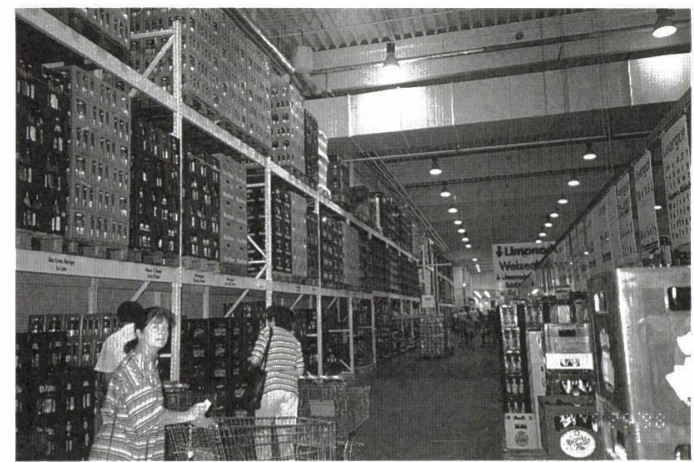

写真 3 スーパーでの売場 
また,購入後の買い物袋は有料で30ペニヒである. だから，消費者は自宅から買物袋，かごなどを持参 している.

\section{3 環境活動}

当社は「環境活動基準」を作成し，それに基づい て, 各店舗の環境計画, 実行, 監査をしている.そ して経営者, 従業員すべてがマスターしておかねば ならないものであり, そのためのセミナーも義務づ けている.

環境活動としては, 品揃え, 仕入れ, 包装, 店舗 の設備と経営の各セクションで基準をつくり実施し ている.

店舗と経営の環境基準には,(1)エネルギーの問題, (2)水の問題，(3)ごみ排出の問題をあげ，それぞれに ついてきめ細かく基準を決めて実施している。

\section{4.〔事例 3〕アルガウリサイクリング(株)}

\section{1 企業理念}

アルガウリサイクリングは 2 つの企業が提携して 1990年に設立された。毎年増え続ける自動車の解体 を見込んで設立したものである。従業員は, 現在経 営者を含めて 39 人である。

設立前のかつての企業の目的は，主として，ガラ ス, 古紙, 金属, 段ボールのような再生資源の回収 と分別であった。同時に, DSD 社の契約者として市 内の回収品の取扱いが主であった。今も，もちろん この業務はもとの会社では本業として営業してい る.3,000ケ所のリサイクル用のコンテナを回収して いる.

環境問題への関心の高まりやリサイクルの経済性 という観点から, 再生資源の市場価值を高めるため に，より専門的な技術革新の必要性がでてきた。

とくに従来, 廃家電, 自動車は簡単な解体で, ほ とんどシュレダーで破砕し金属だけを回収し，ダス トとして埋め立てていた。

それをできるだけ再利用できる部品を回収し，そ して処理にこまっていたオイル，フロンなど環境に 有害な物資を回収し，そして，有価物を機械で回収 するシステムをつくる必要性が生じ，新規にこの会 社を設立した。

\section{2 「循環経済・廃棄物法」への対応}

1994年にこの法律は制定された.この基本理念は， 経済も含めてすべてのことを環境をべースに考慮し なければならないという厳しいものである。
これがこれからのドイツの基本法であり，これに よって業種ごとの個別リサイクルが規制されるので ある。それが「容器包装回避に関する政令」であり， 次に，控えているのが，「自動車リサイクル規制令」, 「電気・電子機器リサイクル規制令」などである.

「自動車リサイクル規制令」は，1990年に公表さ れ, 毎年修正政令案がだされ, 特に, シュレダーダ ストに関する規制は㛜しくなっている。

ドイツ全体で, 約 3,100 万台の車が使用され，その うち廃棄されるのが, 年間約260万台である. 現在の 国の平均的データは，金属部品が年間45万トン, 夕 イヤが15万トンで，それ以外のプラスチック部品お よびガラス類は廃棄処分されているのが実態であ る.そこで, 自動車の再利用率を高め, 解体処理に 伴って排出されるシュレダーダストを減らすため に, 政令が定められ，それに向かって経営努力がな されているのである。

メーカーあるいは販売者は，販売店舗と同じ数以 上に廃車の回収施設を設置しなければならない。そ こではエンドューザーから無料で廃車を引き取り, 可能な限り再利用することが義務づけられている。 同時に, メーカーでは, プラスチックの部品にすべ てその素材表記に番号をつけることが検討されてい るがまだ制度化はされていない.素材別については, 努力目標として次のようにさだめられている.

$\begin{array}{lrr} & 1996 \text { 年 } & 2000 \text { 年 } \\ \text { 鉄 鋼 } & 100 \% & 100 \% \\ \text { プラスチック } & 85 \% & 95 \% \\ \text { タイヤ } & 40 \% & 50 \% \\ \text { ガラス } & 30 \% & 50 \% \\ \text { その他 } & 20 \% & 30 \%\end{array}$

このようなドイツの政令化のもとで, 当社は将来 のモデル的な自動車の解体施設を建設し, 昨年より

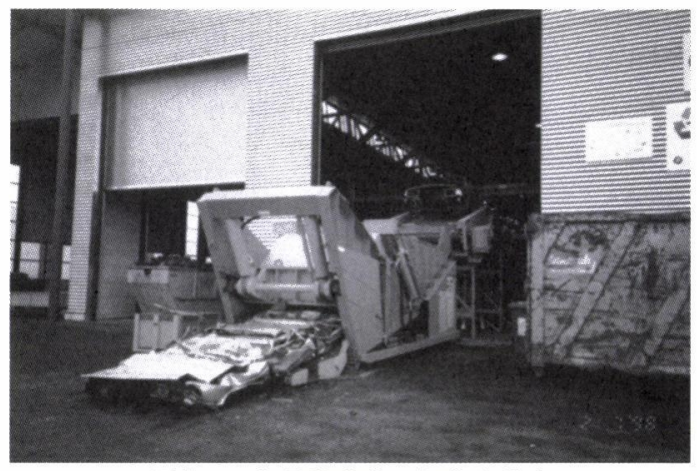

写真 4 部品除去後の解体自動車 


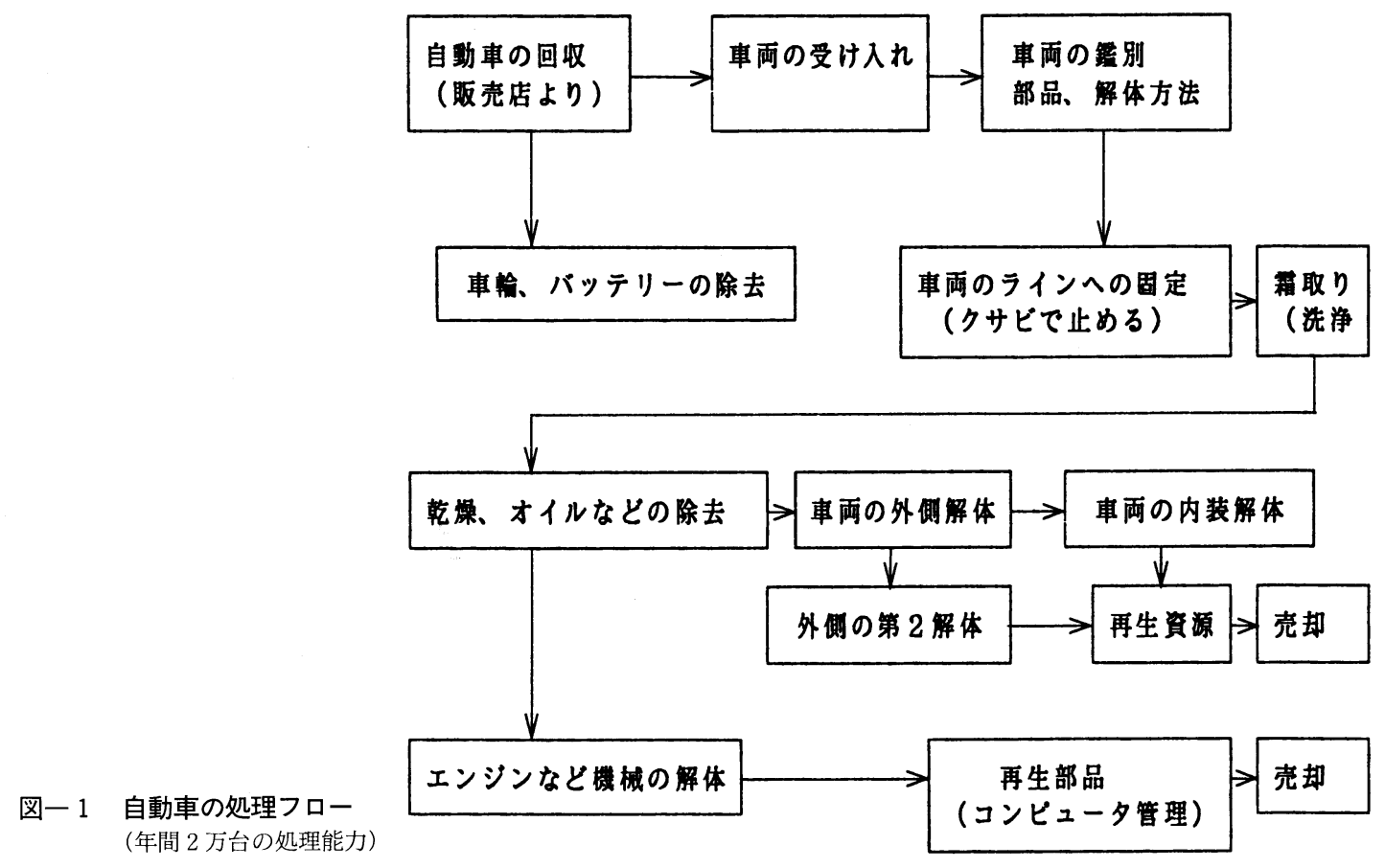

稼㗢を始めた。

シュレダーダストを少なくするため，シートベル

ト，シート，フロアなども回収してリサイクルして いる．また，エアバッグは回収後，ガスを爆発させ ておかねばならないなど目新しいものが見学できた

(写真 4 , 図一 1 ).

当社のシステムでの 1 台の自動車から再利用でき る部品を約 50 種類ほど引き取り，それが全車両の 50 \%ほどになる。

\section{3 家電製品の回収と解体}

実験的であるが，冷蔵庫を中心に解体を昨年より 実施している．販売店より 1 台約 25 マルクで引き取 り, 何年型かを鑑別し，それからラインに固定し， まずフロンを 5 分間ほどで回収する，そして，冷蔵 庫を回転して，コンプレッサーを取り，つぎに断熱 材を除去し，大型機械で解体，破砕し，鉄類，非鉄 類，プラスチック類，その他に分別している. 